\title{
TRANSLATION AS A METHOD IN TEACHING ESP: AN INDUCTIVE THEMATIC ANALYSIS OF LITERATURE
}

\author{
Viktorija Mažeikienè \\ Institute of Humanities, Mykolas Romeris University, Lithuania \\ E-Mail: viktorija.mazeikiene@gmail.com
}

\begin{abstract}
Using translation in ESP teaching and learning is an important issue but it has been very scarcely researched so far because of the negative connotations with the grammar-translation method. But since the last decade of the $20^{\text {th }}$ century, revival of interest in the use of translation and use of L1 in foreign language teaching has been noticeable. Therefore, the main aim of this paper is to analyse academic publications on the use of translation (and L1) in the ESP teaching and learning in order to see what aspects are raised by researchers and practitioners as regards the efficiency of translation as a teaching method in ESP classes in higher education. The objectives of this paper are: (1) to see what important and telling themes are evident in the selected academic publications, and (2) to analyse the attitudes of the authors of the papers towards using translation as a supplementary teaching method in teaching/learning ESP. For this paper, inductive thematic analysis has been chosen as a useful qualitative analytic method (Brown and Clarke 2006). The data corpus for this paper (14 quality papers) has been collected by conducting a systematic literature search of two academic online databases: EBSCO Academic Search Complete and Web of Science. Initially, emerging themes have been grouped under two headings - learner needs and teaching practices - and elaborated further on as specific themes: defining learner profile, course design, translation as a communicative activity, focusing on accuracy, facilitating understanding, defining specific tasks, consolidating particular skills, balancing the amount of translation in the ESP classroom. The inductive thematic analysis of the academic publications done for this paper shows that translation-based activities are useful for the ESP learner and that translation is an efficient ESP teaching and learning method if the amount of translation done is well-balanced, activities are well-planned and the learner profile and needs in each specific course well-analysed. Translation activities consolidate reading, writing, speaking and listening skills of the ESP learners, facilitate communication and comprehension of a specific field, develop analytic skills and teach to focus on accuracy.
\end{abstract}

Key words: ESP, translation, teaching method, inductive thematic analysis

\section{INTRODUCTION}

Using translation-based activities in English for Specific Purposes (ESP) teaching/learning is an important issue but it has been very scarcely researched so far for a seemingly obvious but unsubstantiated reason. As it has been noted by some researchers (Chirobocea 2018; Marinov 2016), translation as a teaching method was associated with the grammar-translation method for a very long time and, consequently, the use of translation in teaching a foreign language (and the use of L1 in L2 instruction) have been unduly criticised. The reason for this was promptly stated by Weschler who agreed that the grammar-translation method did not work but criticized "[...] the unstated

Submitted August $31^{\text {st }}, 2018$, accepted for publication October $25^{\text {th }}, 2018$ 
assumption that it was the act of translation itself which lay at the root of the problem." (1997: 88; italics in the original). In fact, translation has never lost importance in practical situations of teaching, especially in the context of ESP, at least as a supplemental method (Chirobocea 2018: 67). Revival of interest in the use of translation and use of L1 in foreign language teaching has been observed since the end of the $20^{\text {th }}$ century (Malmkjaer 1998 cited in Leonardi 2009: 143; Atkinson 1987 cited in Chirobocea 2018: 70; Marinov 2016: 229; Poljaković 2016: 340). Translation has started to be seen as a useful tool in teaching English as a Foreign Language (EFL) and ESP (Chirobocea 2018; Leonardi 2009); the use of L1 in ESP instruction has also started receiving considerable attention of researchers (Poljaković 2016). Therefore, the main aim of this paper is to analyse some articles on the use of translation (and L1) in the ESP teaching and learning in order to see what aspects are raised by researchers and practitioners as regards the efficiency of translation as a teaching method in ESP classes in higher education. The objectives of this paper are: (1) to see what important and telling themes are evident in the selected academic publications, and (2) to analyse the attitudes of the authors of the papers towards using translation as a supplementary teaching method in teaching/learning ESP.

\section{A ‘TRANSLATION TURN’ IN TEACHING ESP}

Since the beginning of the $21^{\text {st }}$ century, a number of researchers have pointed out the advantages of using translation in foreign language teaching. Leonardi (2009), for instance, draws on Malmkjaer (1998 cited in Leonardi 2009: 143) and maintains that "Translation is more and more frequently evaluated as a positive form of interference aimed at enriching rather than harming learners' competence and performance skills. The use of translation in language classes might, of course, have some limitations but also benefits should be explored and taken into consideration." Marinov (2016: 229) points to the development of the post-communicative cognitive paradigm and promising prospects for translation in the ESP context. As regards ESP teaching and learning, any course has to be based on specific learner needs (Dudley-Evans and St. John 2012: 4). These specific needs define selection of materials and teaching/learning methods. Marinov (2016: 227) maintains that "Translation is an activity or a strategy naturally employed by both language teachers and learners. Accordingly, despite some possible limitations, its potential should be studied and exploited since it could help language learners gain deeper understanding of what they do when they move between the two languages and thus indicate the areas that might need improvement."

Importantly, teaching ESP and employing translation as a method of teaching and learning does not require from ESP learners in-depth knowledge of translation theory as it is required of translation students. As noted by Witte (2009 cited in Kic-Drgas 2014: 258, "It is not essential to be an expert in translation and translation theory to use translation in class". But translation activities used for learning ESP and the use of L1 can contribute to facilitate comprehension of specialised materials in the ESP classroom and improve learners' skills (Avand 2009: 45).

Construction of specialised field knowledge requires complex use of L1. Kavaliauskienè and Kaminskienè (2009: 171) believe that building knowledge of a specialised domain in a foreign language implies demanding tasks in the ESP classroom. In the ESP context, it implies that L2 may cause considerable tensions for the ESP learner. This is why the use of L1 and translation activities may be needed by the ESP 
learner and why the use of mother tongue and translation may facilitate comprehension of specialized texts (Kic-Drgas (2014: 259). Moreover, translation of stimulating materials involving multi-modal texts (for instance photographs and other visual representations of reality), as it is further noted by Kic-Drgas (2014: 260), inspires learners' creativity. Thus, ESP and translation as a teaching method is a multi-faceted issue that continues to be raised by researchers who see it as deserving a closer analytic look and needing rethinking.

\section{METHODOLOGY}

For this particular paper, thematic analysis (TA) has been chosen as a useful qualitative analytic method (Brown and Clarke 2006). It has been assumed at the start of this research that it is necessary to see what aspects are highlighted by researchers as relevant in using translation as one of the methods in teaching ESP. Brown and Clarke define TA as "A method for identifying, analyzing and reporting patterns within data." (2006: 79). Brown and Clarke distinguish between two types of TA: inductive and theoretical. Theoretical TA builds on hypotheses and existing theories. Inductive TA does not stem from any particular theory but is grounded in empirical data acquired by the researcher. For this paper, inductive TA has been done in order to see what themes emerge in academic publications regarding the use of translation in the ESP classroom. The data corpus for this paper has been collected by conducting a systematic literature search of two academic online databases: EBSCO Academic Search Complete and Web of Science. For this paper, articles have been collected by conducting a basic search for "ESP AND translation" among publications spanning 1980-2018. Only relevant full-text and high-quality papers have been selected for this TA (14 articles in total). After the corpus of academic papers had been finalised, the texts were systematically analysed. TA, according to Brown and Clarke, involves 6 inter-related phases: (1) familiarising yourself with your data; (2) generating initial codes; (3) searching for themes; (4) reviewing themes; (5) defining and naming themes; and (6) producing the report (2006: 35). The data for this paper has been analysed and described following the guidelines provided by Brown and Clarke (2006). Below the findings of the TA are described in detail.

\section{FINDINGS}

Emerging telling themes have been initially grouped under the headings of specific learner needs and a set of teaching practices. Further on, the headings were specified by attaching to them recurring specific themes that were evident in the articles analysed for this paper. 
Table 1 Themes defined during the inductive thematic analysis

\begin{tabular}{|l|l|}
\hline \multirow{3}{*}{ Learner needs } & Themes \\
\cline { 2 - 2 } & Defining learner profile \\
\cline { 2 - 2 } & Course/syllabus design \\
\hline practices & Translation as a communicative activity \\
\cline { 2 - 2 } & Focusing on accuracy \\
\cline { 2 - 2 } & Facilitating understanding \\
\cline { 2 - 2 } & Designing specific tasks \\
\cline { 2 - 2 } & $\begin{array}{l}\text { Consolidating particular skills through translation } \\
\text { or translation as the fifth skill (encompassing the } \\
\text { other four or consolidating a particular one) }\end{array}$ \\
\cline { 2 - 2 } & $\begin{array}{l}\text { Balancing the amount of translation activities in } \\
\text { the ESP classroom }\end{array}$ \\
\hline
\end{tabular}

\subsection{Learner needs}

\subsubsection{Learner profile}

Several aspects are pointed out by researchers as regards the efficiency of activities involving the use of L1 or translation in the ESP classroom. Simões, Guincho and Magalhães (2013: 54), for instance, note that many high school graduates have not necessarily achieved levels B2 or at least B1 in English, their observed levels can go down to A2 even and although the students can communicate informally and orally quite effectively in daily situations, their skills are not sufficient for the ESP classroom. In addition, for translation to be an effective method in the ESP classroom, the classroom should be monolingual (Simões, Guincho and Magalhães (2013: 53).

In deciding whether and how much translation is needed in an ESP setting, ESP teachers have to take into consideration the fact that foreign language learners translate mentally. Some researchers (Weschler 1997; Chirobocea 2018) note that the decision not to use L1 and translation in foreign language classroom is "[...] neither reasonable, nor justified for many reasons" (Chirobocea 2018: 68). Chirobocea (2018, 68-69) further maintains that "An important argument in this regard is that all students translate mentally (Duff, 1994, quoted in Dagiliene, 2012: 125; Cook, 2001:417), especially in elementary levels, but not only, and using L1 comes naturally, as Jeremey Harmer points: "when we learn a foreign language we use translation almost without thinking about it, particularly at elementary and intermediate levels" (Harmer, 2001: 131). The rigid elimination of the use of L1 in the classroom is not a solution, not a guarantee for the improvement of language acquisition (Matiolli, 2004: 25), especially since it is the learners' preference to use it (Atkinson, 1987: 242; Tudor, 1987: 269)". What is more, some researchers note that translation is of special importance at intermediate and advanced levels as well because of its social nature (Janulevičienè and Kavaliauskiené 
2015: 39) or because in ESP “[...] just good command of English is not enough" (Chirobocea 2018: 71). Kavaliauskienè and Kaminskienè (2009: 176) maintain that translation activities are especially important at intermediate and advanced levels as translation is regarded as the fifth skill alongside reading, speaking, listening and writing. What is more, "[...] translating activities may reveal individual strengths and weaknesses in the use of the language." (Kavaliauskienè and Kaminskienè 2009: 183).

In researching the use of translation as a teaching method, researchers characterise translation activities as "natural" and "instinctive". For instance, Simões, Guincho and Magalhães (2013: 50) admit that translation can be viewed as "[...] an instinctive device and resulting useful tool" and that "[...] a translation strategy of referral to the mother tongue could partake one of the methods used in language teaching since it is a natural part of human individuals." Simões, Guincho and Magalhães (2013: 52) build on the findings of cognitive theories and point out: "Most advantages of translation use in the classroom can include a sense of security especially when related to the affective factor of cognitive education (Dilkova 451; Liao 201; Machida). It is a continuation of a natural tendency connecting the learner's familiar world (mother tongue) to an unfamiliar one (target language)."

The fact that ESP learners may have to do translation in their future jobs is highlighted by Medrea (2012) who maintains that, in the field of Legal English, learners may face the challenge of translating not words, but legal systems (2012: 5478). Çelik and Topkaya (2016: 326) admit that though translation as an activity may sometimes be criticised, their research data indicate that such a method meets students' needs.

\subsubsection{Course design}

As it is noted by Chirobocea (2018: 69), “[...] translation used as a teaching technique requires the use of authentic materials, is interactive, learner-centred, and promotes learner autonomy (Mahmoud, 2006: 30), which are also important qualities in ESP". Guerid and Abdellatf Mami (2017: 778) in their article on designing an ESP course for finance managers of a specific company report that, according to their study which looked into learner preferences regarding teaching and learning methods and materials to be used in the course, different teaching methods should be used in an ESP course to meet specific ESP learners' needs and therefore, they suggest eclecticism, similarly to Çelik and Topkaya (2016: 330). Marinov (2016: 227) notes that "[...] potential limitations or pitfalls of translation exercises can be predicted and remedied by carefully designing teaching activities involving translation." Laviosa and Cleverton (2006: 3) emphasise the importance of translation competence in ESP, both from and into the foreign language, in contemporary curricula.

\subsection{Teaching practices}

\subsubsection{Translation as a communicative activity}

Claims that translation activities do not develop communicative skills arose because of the obvious fallacies of the grammar-translation method and the prevalence of communicative methods in the $20^{\text {th }}$ century. Contrary to such claims, contemporary 
researchers point out certain aspects regarding efficiency of translation-based activities in developing primarily communicative skills. Chirobocea (2018: 69), for instance, notes that "[...] contrary to the general belief, translation as a teaching method is communicative, as Ana B. Fernández-Guerra suggests: "as a communicative act, TILT [translation in language teaching] can expose FL students to various text types, registers, styles, contexts, etc. that resemble the way languages are used in real-life for communicative purposes. (2014: 155)." Similarly, Simões, Guincho and Magalhães (2013: 65) maintain that translation is a real life communicative activity. Leonardi (2009) refers to Nord (1997 cited in Leonardi 2009: 145) who also maintains that translation is a communicative activity. Leonardi further writes: "Translation involves interaction between the teacher and the students to discuss rights and wrongs as well as problems related to translation task. If this communication exchange takes place in the L2 before and after the translation this can help students enhance their oral skills (both listening and speaking)." Janulevičienè and Kavaliauskienè (2015) refer to Kaye's view regarding the use of translation activities in language classroom and its advantages and drawbacks (Kaye 2009 cited in Janulevičienè and Kavaliauskiene 2015: 39) and note that "[...] translation is a real-life, natural activity [...]" and "In terms of communicative competence, it helps to master accuracy, clarity and flexibility" (2015: 39). Furthermore, the authors refer to findings by Ross (2000 cited in Janulevičienè and Kavaliauskiene 2015: 39) and maintain that "[...] translations from the L1 to the L2 and from the L2 to $\mathrm{L} 1$ are recognized as the most important social skills since they promote communication and understanding between strangers." Leonardi (2009) focuses on translation in teaching business English and maintains that "Translation is a mediating activity which always takes culture-bound terms and concepts into account in order to be successful in its transposition of a text from one language to another. Business and financial texts are characterised by a large number of culture-bound terms and references which should be known by students in order to boost their comprehension of texts" (2009: 150) and further points out that "Translation, therefore, becomes a form of cultural mediation which is needed in order to carry out communication across cultures" (2009: 151).

\subsubsection{Focus on accuracy in ESP through translation activities}

In her considerations about the efficiency of translation-based activities in teaching and learning ESP, Chirobocea (2018: 70-71) notes that though the Communicative Approach is widely acknowledged as the best method in foreign language teaching when it is assumed that phonological, grammatical or spelling accuracy is less important, "There are, however, fields where accuracy matters and is actually vitally important, like science, for example. [...]. Thus, in teaching scientific English, that is ESP for science students, it is very important to match their future needs". Chirobocea further (2018: 71) maintains that "When it comes to ESP, the question of purpose (Kic-Drgas, 2014: 256257) and learners' needs is stronger than in EFL. Translation may not be suited for all learners, but it is very helpful in ESP where accurate equivalence, as well as work on authentic texts are required for the learners' needs."

Focus on in-depth analysis of a text and its specific features is an integral essential stage in the translation process. This stage is also very important in studying specialised texts. As regards ESP teaching, Kic-Drgas (2014: 257) highlights: "On the ground of teaching it is the specialized text which provides correct patterns of using language in the 
specialized context. Without in-depth analysis of original documents an ESP teacher or learner will not have an idea how the particular specialized language functions, what structures or collocations are typical for the specific domain."

\subsubsection{Promoting understanding}

According to Leonardi (2009: 145), a conversation about translation problems in ESP classroom facilitates understanding of a text by relating the analysed text with relevant topics studied in students' L1. Besides, Leonardi (2009: 143) highlights the contribution of translation to improved understanding and deeper analysis of a specialised text: "Before starting translating a text, the source text (ST) should be read carefully and analysed in detail. Thus, through close reading and careful text analysis of the ST students can gain important insights into the comprehension of the text in order to avoid misinterpretations and/or misunderstandings." Close reading, careful text analysis, and comprehension are aided by what Chirobocea, following Atkinson (1993 cited in Chirobocea 2018: 69), points out as thinking about meaning, thinking comparatively, and real-life needs: "[...] some of the benefits of using translation activities are that they force learners to think about meaning, not just manipulate forms mechanically, allow learners to think comparatively, encourage them to take risks, and are a real-life activity (the learners may need to translate in their job) (Atkinson, 1993, 53-54)." Similarly, Marinov (2016: 227) notes: "Scott and Pavlenko (2008: 217) claim that L1and translation can help "raise awareness of negative transfer through cross-linguistic comparisons". [...]. Mastering one-to-many correspondences and L1 transfer are merely two of the many problems of acquiring a foreign language. If they are encountered in a translation exercise teaching or learning can occur." Working on parallel texts, according to Kic-Drgas (2014: 260), consolidates knowledge of particular lexical structures in both languages. Also, Chirobocea (2018: 71) views the ESP class as a time for learners to consolidate their scientific knowledge through a possibility to look for relevant information on their own. Similarly, Kic-Drgas (2014: 260) notes that translation of longer texts can be an important part of an ESP class and acquiring specific-domain knowledge in general.

\subsubsection{Specific tasks}

It is important to consider using translation for learning purposes in the ESP classroom because, as it has already been mentioned above, doing mental translations is very important for learners no matter how good they are. As Leonardi (2009: 141) maintains, "The role of translation is thus fundamental in teaching and showing students mediation strategies and both linguistic and cultural differences through employing a contrastive approach to language. Through translation, students can learn more about problem-solving strategies, improve their analytic skills and strengthen their grammatical and lexical competence and performance." Kic-Drgas (2014: 253) views translation as "an integral part of ESP teaching".

In addition to raising cultural understanding, translation in the ESP classroom, as Leonardi (2009: 144-145) points it out, involves similar activities and processes that are involved in composition writing, summary writing, paraphrasing, drawing conclusions, solving problematic issues. As Leonardi (2009: 145) notes, "Translation can be used to 
teach and eventually test reading, writing, listening and oral skills and if applied to an ESP context, then it can even serve the role of enhancing specific needs. These needs include grammatical, lexical and cultural knowledge."

A range of specific translation-based activities are used by ESP practitioners who believe that the specific translation tasks that they have tried out raise learners' awareness of vocabulary, grammar, style and language transfer. Laviosa and Cleverton (2006), for instance, describe their contrastive translation-based methodology for ESP learning and translation through real-life communicative activities. The methodology consists of six related stages: motivation (introducing lexical features of the source text and potential strategies to approach differences between source and target languages); global comprehension (introducing a translation brief), analysis (guided by questions about problematic issues to be considered in translation), reflection (on problems and possible solutions), synthesis (draft translation), and control (comparing and evaluating translations). As a result, students "[...] have been able to reflect on lexico-grammatical mismatches between the source and target language and propose well reasoned translation solutions [...]" (Laviosa and Cleverton 2006: 11).

As noted by Simões, Guincho and Magalhães (2013: 54), didactic materials for an ESP classroom have to be "home-made" because "It is unlikely to find instant made exercises from course books or the Internet. Furthermore, the exercise done for one group may not be able to be used for another one - even if very similar." Marinov (2016), for instance, has tried to combine translation exercises with a small scale concordance exercises to see how useful such activities can be if used in combination. Properly prepared translations exercises, according to Kic-Drgas (2014: 259), include pretranslation exercises, especially comments on equivalence and differences and similarities between languages.

\subsubsection{Consolidating particular skills and translation as the fifth skill}

Leonardi (2009: 143) believes that "Translation should not be seen, and consequently treated, as a completely different language skill as compared to Reading, Writing, Speaking and Listening because it is an activity which includes them and is, to a certain degree, dependent on them." As it is noted by Chirobocea (2018: 71), translation can be used at elementary levels to improve grammar knowledge, and, as regards higher - intermediate and advanced - levels, "[...] translation may be used to correct errors and point out interference and negative transfer (Newark, 1991, quoted in Ross, 2000; Popovic, 2001), in other words work on nuances and improve knowledge of L2." A number of researchers refer to translation as the fifth skill alongside reading, writing, speaking, and listening (Chirobocea 2018: 71; Leonardi 2009: 142; Janulevičienè and Kavaliauskienė 2015: 39; KicDrgas 2014: 258; Kavaliauskienė and Kaminskienè 2009: 176).

Though some researchers maintain that translation can be used to consolidate grammar at elementary level (Chirobocea 2018: 71), Leonardi (2009: 145-146) believes that though generally ESP students know grammar well enough, "It is worth noting, however, that in particular specialised fields grammar may be characterised by a special set of rules. Broadly speaking, Business English is characterised by its simplicity, precision, objectivity, efficiency and courtesy. This implies a different way to use grammar in business texts [...]. [...] Authentic texts are characterised by numerous examples of grammatical structures and therefore the ESP teacher needs to identify 
commonly used or re-occurring structures in business texts." According to Chirobocea (2018: 73), translation activities at the end of ESP class or in explaining specific grammar points can reinforce grammar competence.

Leonardi (2009: 148) believes that translation can be a useful method of building vocabulary in the ESP classroom: "In a contrastive bilingual situation, students can, thanks to translation, improve their ability to find an equivalent in L1 to match a phrase in L2. Translation can teach students to learn vocabulary in two stages: students are taught to make a connection between the meaning and the form of the word, and then they must learn when to use or not to use the word, its word relationships, its nuances, and so on." In addition, working in both L1 and L2 can be a means of preventing mistakes (Simões, Guincho and Magalhães (2013: 52). Translation of sentences from certain contexts (specialised texts) implies focusing on important ESP phrases and terms which, in turn, leads to learning of new vocabulary and its proper use (Kic-Drgas 2014: 259). Kic-Drgas also notes (2014: 259) that translation of specific terms from one language to another (and then retranslation a few weeks later) facilitates memorisation and comprehension of meaning because it focuses on issues of equivalence and translation of ideas conveyed by messages, not words.

Building on the premises of cognitive linguistics, Fuertes-Olivera and Piqué-Noguera (2013) look into the implications of the literal translation hypothesis for ESP teaching and learning. Fuertes-Olivera and Piqué-Noguera (2013: 19) seek to understand how learners disambiguate newly encountered terms and refer to the concept of priming: "The maintenance of conceptual affinity, as well as the difficulty that professional translators and students of ESP have to understand some concepts when dealing with specialised texts, offers ground for hypothesizing that both translators of specialized texts and students of ESP are primed for accepting verbatim translations of terms, e.g. terms originally coined in English". Consequently, these authors conclude that it is important to consider information provided by specialised dictionaries in order to disambiguate terms and understand their precise meanings and to determine particular ESP methodologies for disambiguating terms: "We propose to use these methodologies instead of "cloze" and "guess" exercises that are limited to one or two-word terms, i.e., to a very limited stock of the real vocabulary of a specialized domain. To sum up, we propose working with teaching/learning exercises that reproduce real skills, and always demand the use of real language that typically includes multi-word terms" (2013: 28). However, in teaching, Marinov (2016: 226-227) combines translation activities with data-driven learning (DDL) as she sees such combination of methods efficient because of some common characteristics: both of them focusing more on accuracy than fluency, being timeconsuming and laborious, and translation (unwelcome in the communicative approaches but undergoing reconsideration today) being similar to DDL in that DDL, though becoming popular in language teaching, is still lacking user-friendliness.

Translation activities are often viewed as stimulating the development of learners' analytic skills. Development of analytic skills is facilitated by pair and group discussions which, in turn, develop speaking and listening skills. Kic-Drgas (2014: 260) believes that discussion with ESP learners about solutions to difficulties encountered during translation activities are a very important part of ESP instruction. In addition, translation activities are very efficient for developing learners' critical reading skills (Leonardi: 2009: 144).

Finally, balancing the amount of translation activities that can be done in ESP classrooms is an important issue to consider. Atkinson (1993 cited in Kavaliauskienè and 
Kaminskiene 2009: 176) refers to four factors that have to be considered in deciding how much translation can be efficient: learners' previous experience, learners' linguistic level, stage of the course, and stage of the class.

\section{CONCLUSION}

Following the revival of interest in the use of translation and L1 in ESP teaching and learning, the use of translation in the ESP classroom still needs much further research. However, the inductive thematic analysis of the academic publications done for this paper shows that translation-based activities are useful for ESP learners and that translation is an efficient ESP teaching and learning method if the amount of translation done is well-balanced, activities well-planned and the learner profile and needs in each specific course well-analysed. Translation activities can not only consolidate a specific skill (reading, writing, speaking and listening), but translation is often viewed as the inherent fifth skill alongside the other four. Contrary to long-held beliefs that translation as a teaching and learning method is not communicative, contemporary researchers maintain that translation, in fact, facilitates cultural understanding and communication of ESP learners, improves their knowledge of a specific field, develops ESP learners' analytic skills, engages them in cross-linguistic comparisons and, consequently, brings to the fore the much needed focus on accuracy in the ESP contexts and future professional settings.

\section{REFERENCES}

Avand, A. Q. 2009. "Using Translation and Reading Comprehension of ESP Learners". The Asian ESP Journal. Vol. 5 Issue 1: 44-60.

Brown, V. and V. Clarke. 2006. "Using Thematic Analysis in Psychology." Qualitative Research in Psychology 3, No. 2: 77-101. http://eprints.uwe.ac.uk/11735.

Çelik, H. and Topkaya, E. Z. 2016. "Evaluation of the Methodology of an ESP Reading Skills Course for Undergraduate Medical Students: Outsider Perspective". ProcediaSocial and Behavioral Sciences 232: 326-331.

Chirobocea, O. 2018. "A Case for the Use of Translation in ESP Classes". Journal of Languages for Specific Purposes Issue 5, 67-76.

Dudley-Evans, T. and St. John, M. J. 2012. Developments in English for Specific Purposes. A Multidisciplinary Approach. Cambridge: Cambridge University Press.

Fuertes-Olivera, P. A. and Piqué-Noguera, C. 2013. "The Literal Translation Hypothesis in ESP Teaching/Learning Environments". Scripta Manent 8(1): 15-30.

Guerid, F. and Abdellatif Mami, N. 2017. "Designing an ESP Syllabus for Finance and Accounting Staff'. The Journal of Teaching English for Specific and Academic Purposes. Vol. 5 No. 4: 771-780.

Janulevičienè, V. and Kavaliauskienė, G. 2015. "ESP Students' Self-Evaluation and Attitude Towards Translation”. Journal of Language and Literature Vol. 6 No. 2: 38-43.

Kavaliauskienè, G. and Kaminskienè, L. 2009. "Proficiency in Reading, Writing and Translation Skills: ESP Aspect”. Vertimo studijos. Vol. 2: 171-184. 
Kic-Drgas, J. 2014. "Translation in the ESP Teaching". The Journal of Teaching English for Specific and Academic Purposes. Vol. 2 No. 2: 253-261.

Laviosa, S. and Cleverton, V. 2006. "Learning by Translating: A Contrastive Methodology for ESP Learning and Translation.” Scripta Manent 2(1): 3: 12.

Leonardi, V. 2009. "Teaching Business English Through Translation". Journal of Language \& Translation 10-1 March 2009, 139-153.

Marinov, S. 2016. "Translation Exercise Aided by Data-driven Learning in ESP Context”. ESP Today Vol. 4 (2), 225-250.

Medrea, N. 2012. "Cross-cultural Communication - A Challenge to English for Legal Purposes". Procedia - Social and Behavioral Sciences 46: 5475-5479.

Poljaković, I. 2016. "Using the First Language in the ESP Classroom at University Level". Metodologija i primjena lingivističkih istraživanja. S. L. Udler, K. Cergol Kovačević (ur.). Zagreb: Hrvatsko društvo za primijenju lingvistiku, 337-347.

Simões, D., Guincho H., and Magalhães, I. 2013. "Teaching Languages to European Computer Science Students". e-TEALS. No. 4: 46-70.

Weschler, R. 1997. "Uses of Japanese in the English Classroom: Introducing the Functional-Translation Method". Paper presented at the Annual Meeting of the Japan Association of Language Teachers (23 $3^{\text {rd }}$, Hamamatsu, Japan, October 9-12, 1997. Retrieved http://iteslj.org/Articles/Weschler-UsingL1.html . 